\title{
9
}

\section{Positive Free Speech and Public Access to Courts}

JUDITH TOWNEND

Even the most casual observer of courts in the UK, whether through crime dramas or news reports, will likely have some awareness of the guiding principle that for justice to be done, it must be seen to be done. But if one digs beneath that popular and well-cemented phrase, understood as critical to the rule of law, it becomes clear that open justice takes many different forms, and is in practice a complex principle to administer and enforce. Clearly, the UK courts have a positive obligation in law to provide information about their activities, but to what extent? ${ }^{1}$ Just how much, and by what method and why, are questions that are contested and open for interpretation.

This chapter uses the positive free speech framework and normative arguments forwarded in this collection to address these questions and to suggest how the judiciary and courts service should be publicly communicating what happens in court. Accepting the premise that there are positive duties on the state that insist[s] that everyone be able to exercise their rights'2 in order to 'support diverse speech environments, ${ }^{3}$ and that positive free speech is a 'central element existing alongside concerns about legal limitations on speech, ${ }^{4}$ it proposes a way forward for further enhancing positive free speech in a court setting.

The chapter first sets out an explanation of the way in which courts are accessed, at both the theoretical and the practical level. It then uses two case studies, a recent terrorism trial and a public inquiry, to examine further the way that courts are accessed in practice. Lastly, it considers the relevance of the government's 'open government' and 'open data' policy agenda. ${ }^{5}$ When taken as a whole, this account suggests that there are existing negative and

\footnotetext{
${ }^{1}$ This chapter focuses on courts in England and Wales and at a UK level (eg UK Supreme Court); it does not attempt to assess the situation in Scotland and Northern Ireland. All websites accessed in July 2019 unless otherwise stated.

${ }^{2}$ S Fredman, Human Rights Transformed: Positive Rights and Positive Duties (Oxford, Oxford University Press, 2008) 30 .

${ }^{3}$ AT Kenyon, 'Assuming Free Speech' (2014) 77 MLR 379, 391.

${ }^{4}$ ibid 380 .

${ }^{5}$ This chapter develops case studies discussed in two previous articles: J Townend, 'Leveson Online: A Publicly Reported Inquiry' (2013) 10 Ethical Space 14 and H Irving and J Townend, 'Censorship and National Security: Information Control in the Second World War and Present Day' [2016] History \& Policy, www.historyandpolicy. org/policy-papers/papers/censorship-and-national-security-information-control.
} 
positive free speech elements to reporting and accessing courts in English law, but that the judiciary and courts service need to do more to protect an important positive liberty for all citizens.

\section{Free Speech in the Courts}

\section{A. Open Justice Principle in Theory and Practice}

The root of open justice runs deep, and it has grown and developed over centuries during which there have been dramatic technological and social shifts. In fact, it came about 'almost by historical accident' as an evolution of the public gatherings at court in the Middle Ages. ${ }^{6}$ Over time, the principle was succinctly articulated as an essential component of justice and an important means of ensuring a fair trial, which is protected under Article 6 of the European Convention on Human Rights (ECHR), as well as in the common law.

The open justice principle has served a number of purposes relating to court access. ${ }^{7}$ For Robertson and Nicol, 'trials derive their legitimacy from being conducted in public.' They, and other scholars, offer a range of associated benefits of this public justice: it discourages perjury and protects against judicial error; it protects the parties from an unfair trial; and it helps maintain public confidence in the courts. These factors can be described as part of the accountability rationale.

Robertson and Nicol also suggest factors which are less well interrogated in judicial decisions: reporting 'enhances public knowledge and appreciation of the workings of the law', and it 'permits the revelation of matters of genuine public interest.' These, I suggest, can be described as the education rationale, particularly important at a time when cuts to legal aid have created a growing number of litigants-in-person, and when many civil claims are resolved out of court owing to the high financial and personal cost of defending or bringing claims. The education justification is extended with the proposition, acknowledged by the courts in some instances, ${ }^{10}$ that the media needs to know particular details of cases to attract readers, and less tenably, to ensure news organisations' financial survival. ${ }^{11}$

Finally, there is the deterrence rationale: the argument, usually made in debates over the naming of individuals, that publicity of proceedings deters the parties and the wider public from committing future offences; as part of this process, the public and press are able to judge the named individuals involved. This is often described as 'naming and shaming, although it is also arguable that deterrence can be achieved even with anonymisation. Open justice in the Middle Ages may have been motivated by the logic of this third category, but it is perhaps the least convincing rationale for complete openness of proceedings.

\footnotetext{
${ }^{6}$ G Robertson and A Nicol, Media Law, 5th edn (London, Penguin, 2008) 463.

${ }^{7}$ The open justice principle is so well embedded it is often accepted uncritically. A notable exception is the critique by J Jaconelli, Open Justice: A Critique of the Public Trial (Oxford, Oxford University Press, 2002).

${ }^{8}$ Robertson and Nicol (n 6) 464.

${ }^{9}$ ibid 464.

${ }^{10}$ eg ETK v News Group Newspapers Ltd [2011] EWCA Civ 439, [13].

${ }^{11}$ See M Amos, 'The Positive Right to Freedom of Expression and Party Anonymity in Legal Proceedings', this volume, ch 8 .
} 
As the presiding judge found in a recent and rare case, when upholding the anonymity of the two convicted teenage defendants who were found guilty of murdering 39-year-old Angela Wrightson: it is arguable that no further deterrence is necessary or, if it is, the naming of the individuals will add little to the fact that those responsible have been brought to justice, been convicted and been sentenced.' ${ }^{12}$

The rationales for open justice are wide-ranging, but the justifications for derogations from the principle - at least in theory - are more concise. According to the common law, for courts to hear a case in private, it must be deemed that there is a serious possibility that open proceedings would render impractical or frustrate the effective administration of justice: for example, by deterring prosecution of a case. ${ }^{13}$ This will trump any competing argument, including the public interest served by open reporting.

Open justice, justified in the ways described above, is often perceived as meaning complete transparency: that is, everything that takes place in the courtroom should be made public. In practice, justice ranges from opaque to translucent to transparent, depending on the types of proceedings and court or tribunal - there are many shades of open justice. Opacity or translucence is achieved through a range of automatic and discretionary restrictions. In some cases, public access may be denied through the decision to move in camera, that is, into closed proceedings. This is common for parts of sensitive national security cases, for courts hearing privacy injunction applications and in courts such as the Investigatory Powers Tribunal and the Special Immigration Appeals Commission, which hold hearings with no press or public permitted.

In some courts and cases, access may be allowed but reporting is restricted. By way of illustration, in the Court of Protection, a court which makes decisions on cases involving people deemed to lack mental capacity, a transparency regime permits regular access to the public and media with restricted reporting; ${ }^{14}$ in the criminal courts, sexual offence cases can be attended and reported, but victims of a wide range of sexual offences are given lifetime anonymity. A variation of this model allows the postponement of reporting of certain information: for example, only very restricted details of allocation and sending hearings in the magistrates' courts can be reported at a preliminary stage. More problematically, in certain courts and cases, a more limited class of the public are allowed to attend. This is the model used in the family and youth courts, where accredited members of the media may attend private hearings closed to the public, and special reporting restriction regimes apply. ${ }^{15}$ Beyond this range of automatic restrictions, the court can postpone or prohibit

\footnotetext{
12 'Sentencing Remarks of Mr Justice Globe, Leeds Crown Court 7 April 2016’, [57], www.judiciary.gov.uk/ wp-content/uploads/2016/04/sentence-f-d-1.pdf.

${ }^{13}$ See AG v Leveller Magazine [1979] AC 440; Guardian News and Media Ltd \& Ors v Incedal [2014] EWCA Crim $1861,[17]$.

${ }^{14}$ A transparency pilot originally ran from 29 January to 31 July 2016, which was then extended and made permanent under Practice Direction 4C supplementing Part 4 of the Court of Protection Rules 2017, effective from 1 December 2017.

${ }^{15}$ G Millar and A Scott, Newsgathering: Law, Regulation and the Public Interest (Oxford, Oxford University Press, 2016) [10.17]-[10.24]. Among other senior judges, the former President of the Family Division, Sir James Munby, has championed a perceived need to 'open up' the family justice regime. He has contended that 'nothing short of radical reform will enable us to rid ourselves of the relentlessly repeated and inevitably damaging charge that we operate a system of private - some say secret - justice': see J Munby, 'The Family Justice Reforms', speech delivered 29 April 2014, London, https://www.judiciary.uk/announcements/the-family-justice-reforms-remarks-by-sirjames-munby/.
} 
other details - such as individuals' names - being reported on a case-by-case basis. These automatic and discretionary restrictions may protect the administration of justice and a fair trial (by not prejudicing proceedings, for example), and rights associated with child welfare, and private and family life.

As will be shown in the case studies, approaches to digital openness vary greatly, not only between, but also within, different categories of courts. Some courts have been far more proactive in publishing details of proceedings and decisions. Others rely almost entirely upon third party providers, such as the official law reports and the press, to communicate their proceedings. The predominant approach to open justice and access to information taken by the judiciary and Her Majesty's Courts and Tribunals Service (HMCTS), an executive agency of the Ministry of Justice, is protection of a neutral or negative principle, one of non-interference: non-censorship of proceedings (most courtrooms can be visited in person), and a judge may lift restrictions upon application of a third party, such as a newspaper. A positive liberty is also present, if often secondary: in many instances, there is a positive application of open justice, in which the court proactively notifies parties of potential restrictions and publishes details of its work online. Obligations to safeguard the identity of witnesses or journalistic sources may also be seen as part of a positive liberty for those it protects. However, this positive approach, in which the court perceives a positive obligation to notify and inform, is not consistent or reliable across the courts service, and is vulnerable to error and oversight. ${ }^{16}$

The notion that the public should be able to attend court, or have proceedings reported to them via a proxy such as the press, accords well with the freedom of expression concept under Article $10 \mathrm{ECHR}$, which provides a public right to receive and impart information and ideas. ${ }^{17}$ Arguments in favour of increased access have often relied on Article 10. It is, however, the common law principle of open justice which has proved the more reliable weapon in the arsenal in a UK context, as there are limits to how Article 10 ECHR and its domesticated version under the Human Rights Act have been used positively to protect free speech. ${ }^{18}$

\section{B. Right to Report Courts}

Most usually, Article 10 arguments have been articulated with regard to the right to report court proceedings. This builds on Lord Denning's understanding of press reporters as the 'watchdog of justice', that 'every member of the public must be entitled to report in the public press all that he has seen and heard.' ${ }^{19}$ This remark, made in 1955, seems oddly broad for its time: the choice of the word 'report' rather than 'read' corresponds with the 'imparting' component of Article 10, rather than the 'receiving' element. At that time, very few members

\footnotetext{
${ }^{16}$ This is an issue that has been dealt with extensively in the family courts and Court of Protection. See, eg A Healthcare NHS Trust $v$ P \& Q [2015] EWCOP 15.

${ }^{17}$ See Amos, this volume, ch 8 , who discusses the courts' treatment of freedom of expression in relation to party anonymity as directly linked to the principle of open justice and also as a freestanding right.

${ }^{18}$ For a fuller discussion of the European and UK jurisprudence, see A Scott and A Burke, 'The Access to Information Dimension of Positive Free Speech', this volume, ch 4; Amos, this volume, ch 8.

${ }^{19}$ A Denning, The Road to Justice (London, Stevens \& Son, 1955) 64.
} 
of the public would have the means of communicating what they had observed in the public press. Reading it in the twenty-first century, it makes more sense: it suggests that anyone attending court has an entitlement to report the proceedings - which they can now easily do, via their electronic device on freely available social media and blogging platforms. Whether that would have been Lord Denning's intention is open for discussion.

Despite Lord Denning's broad understanding of this public entitlement, court reporting has largely been confined to a specialist - if diminishing - breed of individuals in the twentieth and twenty-first centuries: the reporters producing the official law reports; and journalists employed by agencies, magazines, newspapers and broadcasters as court reporters and legal correspondents. Beyond this, reporting may be said to include any lists, results and transcripts published by the courts or a private provider, and written judgments, increasingly made available freely online.

Online technology has allowed lawyers increasingly to participate in reporting, whether through news items and commentary on their firm's or chamber's website and blogs, or on their own personal blogs. It has also facilitated members of the public to report court proceedings directly, without requiring the cooperation of a professional outlet. Despite this liberating technology, court reporting has remained oddly traditional, with a few exceptions, such as the freelance journalist Peter Jukes's remarkably committed live tweeting of the phone hacking trials for seven months in 2014. The Criminal Practice Directions on tweeting from court make a distinction between representatives of the media and 'legal commentators' on the one hand, ${ }^{20}$ and ordinary members of the public on the other. ${ }^{21}$ The latter category must seek special permission to tweet, whereas the former may tweet from open court proceedings without making a specific application. Nonetheless, a surge in regular citizen reporting is yet to occur, perhaps because it would be time-consuming and expensive to undertake for someone not employed to do so. It is worth noting that Jukes's tweeting was facilitated by a well-publicised crowd-funding initiative.

A more dramatic social development, which is proving an ongoing challenge for the court and the Attorney General's Office, is the social media interaction around the trial, whether involving parties and their families or the broader public. Much of this social media conversation is harmless, but some publications on social network services can threaten to prejudice a trial to a serious degree. In the original trial of two anonymised teenage girls for the murder of Angela Wrightson, for example, prejudicial Facebook activity around the case led to a retrial and a wide-ranging reporting restriction preventing media organisations from linking or posting reports of the case on social media. ${ }^{22}$ Despite these events, a response by the government to its consultation on the impact of social media on criminal trials claimed that social media does not currently pose a threat to the criminal justice system and that the aforementioned case was not representative. ${ }^{23}$ More recently, Stephen

\footnotetext{
${ }^{20}$ The Lord Chief Justice was perhaps thinking of legal bloggers when drafting the original guidance, although the courts do not yet appear to have considered the definition of 'legal commentator', which could be variously interpreted.

${ }^{21}$ Criminal Practice Directions 2015 [2015] EWCA Crim 1567. See generally Millar and Scott (n 15), [10.80]-[10.83].

${ }^{22} R$ (on the application of British Broadcasting Corporation and others) $v F \& D$ [2016] EWCA Crim 12.

${ }^{23}$ Attorney General's Office, 'Response to Call for Evidence on the Impact of Social Media on the Administration of Justice' (5 March 2019), https://assets.publishing.service.gov.uk/government/uploads/system/uploads/ attachment_data/file/783627/Call_For_Evidence_05.03.2019_v2.pdf.
} 
Yaxley-Lennon, the former leader of the English Defence League, better known as Tommy Robinson, was found to have committed a contempt of court after he breached a reporting restriction imposed under section 4(2) of the Contempt of Court Act 1981, by livestreaming a video from outside the public entrance to the court and aggressively confronting and filming some of the defendants as they arrived at court. ${ }^{24}$

\section{Right to Receive Court Information}

As in other discussions on free expression, the right to receive information is often overlooked in favour of a preoccupation with a right to report. This can be partly explained by the courts' passive and reactive approach. Challenges to restrictions are usually brought by media organisations with the financial and legal resources to do so, and their concern tends to be with their right to report what they have observed in court and material that they already hold. On occasion, however, the right to information has been explicitly asserted. In GNM $v$ Westminster Magistrate's Court, the newspaper sought access to documents in extradition proceedings, partly relying on Article 10. Although the appeal court allowed access (breaking 'new ground' in the application of the open justice principle, though not the nature of the principle itself), Lord Justice Toulson's leading judgment was based on the common law rather than European Court of Human Rights (ECtHR) jurisprudence, although he acknowledged that the latter may be seen as supportive of the overall reasoning. ${ }^{25}$

The judgment also illuminates the lack of clarity from the ECtHR on a right to information; as noted elsewhere in this collection, ECHR jurisprudence is evolving on the question of a positive obligation to provide information. ${ }^{26}$ In November 2016, the Grand Chamber of the ECtHR held back from recognising a freestanding right to receive information, confirming that 'the right to receive information cannot be construed as imposing on a State positive obligations to collect and disseminate information of its own motion'. It did, however, recognise that a positive obligation arises in two types of cases: first, where disclosure of the information has been imposed by an enforceable judicial order; and secondly, where access to the information is instrumental for the individual's exercise of his or her right to freedom of expression and where its denial constitutes an interference with that right. ${ }^{27}$ In determining whether a denial of access to information constitutes an interference with an applicant's freedom of expression rights, the following criteria should be considered in a given case: (i) the purpose of the information request; (ii) the nature of the information sought; (iii) the role of the applicant; and (iv) whether the information is 'ready and available.28

While UK challenges such as GNM $v$ Westminster Magistrate's Court and Kennedy $v$ Charity Commission ${ }^{29}$ could be placed within the 'negative free speech' category as attempts by individuals and organisations to remove an obstacle (unsuccessful in the case of Kennedy),

\footnotetext{
${ }^{24}$ HM Attorney General v Yaxley-Lennon [2019] EWHC 1791 (QB), [4].

${ }^{25} R$ (on the application of Guardian News and Media Ltd) $v$ City of Westminster Magistrates' Court [2012] EWCA Civ 420, [88].

${ }^{26}$ See Scott and Burke, this volume, ch 4; Amos, this volume, ch 8.

${ }^{27}$ Magyar Helsinki Bizottság v Hungary, app no 18030/11 (ECHR, 8 November 2016) [156].

${ }^{28}$ ibid [157]-[170].

${ }^{29}$ Kennedy v Charity Commission [2014] UKSC 20.
} 
they could also lead to a positive obligation on courts and other organisations to provide certain information. In this way, GNM has led to a 'default position' in which the media is entitled to have access to documents that have been placed before a judge and referred to in the course of proceedings. ${ }^{30}$ Prior to this case, access to certain court documents was possible, relying on the Criminal and Civil Procedure Rules, but this ruling extended and embedded the position, proving practically useful for journalists in particular. Most recently and importantly, and further entrenching the decision in GNM, the UK Supreme Court has upheld a Court of Appeal ruling that it was within a court's inherent jurisdiction to allow non-parties inspection of a wide range of documents placed before the court or referred to in civil proceedings. ${ }^{31}$

The availability of documents does not guarantee access to all the British public, however. To give a specific example, Part 5 of the Civil Practice Directions permits members of the public, for a prescribed fee, to obtain statements of case in civil litigation from civil courts, including the Queen's Bench of the Royal Courts of Justice. ${ }^{32}$ However, a number of obstacles have meant that this available data has not been readily accessible, though the introduction of electronic filing in 2019 has somewhat improved access. ${ }^{33}$ Most importantly - and this remains so under the new system - the costs are prohibitively high, especially if an ordinary member of the public, or small organisation, wishes to access more than one or two claims at a time. For claims lodged before the introduction of e-filing, ${ }^{34}$ the court must be visited in person, which may inhibit requesters with a disability, or those unable to travel to London during office hours because of other commitments or expense. For older claims made prior to the introduction of e-filing, a final obstacle remains in locating a claim number with which to make an application for case documents; this process involves searching through a large ring binder of case listings, unless the number is retrieved by another means. ${ }^{35} \mathrm{I}$ have previously remarked that it is as if this court's data, publicly available by law, is stored in an open filing cabinet with no drawer handles or labels. ${ }^{36}$ The e-filing system improves this to some degree, but costs remain high, for no obvious reason, given that the court staff are no longer burdened with the physical labour of locating and copying documents.

The availability of orders that restrict reporting is another concern for journalists and other actors. Plans to create a database of such orders for the media were abandoned owing to reportedly 'eye-watering' costs that would be charged to the media by a private contractor. ${ }^{37}$ As with the statements of case, court orders should be publicly accessible on

\footnotetext{
30 'Reporting Restrictions in the Criminal Courts' (Judicial College, 2015) 29, www.judiciary.gov.uk/wp-content/ uploads/2015/05/reporting-restrictions-guide-2015-final.pdf.

${ }^{31}$ Cape Intermediate Holdings Limited v Dring [2019] UKSC 38; Cape Intermediate Holdings Ltd v Dring (Asbestos Victims Support Group) [2018] EWCA Civ 1795.

32 'Practice Direction 5a - Court Documents - Civil Procedure Rules', www.justice.gov.uk/courts/procedurerules/civil/rules/part05/pd_part05a.

${ }^{33}$ Lord Burnett, 'Speech by Lord Chief Justice: Launch of Electronic Filing in the Queen's Bench Division' (15 April 2019), www.judiciary.uk/publications/speech-by-lord-chief-justice-launch-of-electronic-filing-in-thequeens-bench-division/.

${ }^{34}$ According to communication with court personnel.

${ }^{35}$ It may be known and shared by the parties of a case or accessed via a paid-for service, such as Lawtel.

${ }^{36}$ J Townend, 'Closed Data: Defamation and Privacy Disputes in England and Wales' (2013) 5 Journal of Media Law 31.

${ }^{37}$ Anon, 'Law Commission Calls for Reporting Restrictions Website with Paid-For Access', Press Gazette, 26 March 2014.
} 
request, but this usually requires a physical visit to the court. Furthermore, if a journalist or member of the public has not attended every day of a trial, they may be unaware of any discretionary reporting restrictions that have been put in place (they would be expected to know the automatic ones, which raises a different issue about access to legal education in this regard). In 2014, the Law Commission recommended the creation of a portal where members of the public would be able to find out if a postponement order under section 4(2) of the Contempt of Court Act 1981 had been made. ${ }^{38}$ No such system has yet been developed, despite the government's financial commitment to digital court services and the ongoing programme of court reform and digitalisation, ${ }^{39}$ and in any event it would be partial only in terms of its coverage of the range of discretionary restrictions that may be imposed.

The small press office for the judiciary supplies journalists with reporting restriction orders from time to time. It cannot cover all UK courts' activity, however, and may not consider inquiries from other members of the public - such as researchers and legal commentators - with a legitimate desire to report court proceedings. To give one example, Lucy Reed, a specialist family barrister and blogger, who writes for a range of media and legal publications, but who is not an 'accredited' journalist as understood by the family courts, found it extremely difficult to access the reporting restriction orders associated with a series of family judgments related to the high-profile murder of a child. ${ }^{40}$ The judgments had been published online, but had subsequently been removed. Helpfully for Reed, they were made available by the judiciary press office on request, along with details of a reporting restriction order that had been imposed on some, but not all, of their contents. She wished to check whether any other relevant reporting restriction orders were in place before writing about the judgments. She was advised to contact the court directly; it replied, stating: 'all family proceedings are confidential, unless you are a party in the matter we cannot disclose any information to yourself'. It advised her to make an application to the court to seek the information; this is a process that would likely incur a fee of around $£ 200$. She commented on the failings of a system that did not allow non-parties or non-accredited journalists to check the reporting restrictions in a case that was the subject of much public debate: 'what about the self-employed journalist or the blogging citizen journalist ... how are responsible bloggers to know what is and is not prohibited?'41

Happily for Reed, following her charity's application to the Family Procedure Rules Committee, the court has now introduced a pilot which extends access to a limited class of legal bloggers, including qualified lawyers in practice, working for an educational charity or employed by a higher education institution. ${ }^{42}$

There is similarly mixed practice around the supply of court lists. Some lists are made available through a private service called Courtserve, either for free or for a subscription

\footnotetext{
${ }^{38}$ Law Commission, Contempt of Court (2): Court Reporting, Law Com No 344, HC 1162 (London, Stationery Office, 2014).

${ }^{39} \mathrm{See}$ www.gov.uk/guidance/the-hmcts-reform-programme.

${ }^{40}$ This account is based on personal correspondence with Reed and the Transparency Project (of which I am a member) and Reed's blog, www.pinktape.co.uk.

${ }^{41}$ L Reed, 'What Price Transparency?', Pinktape (blog), 25 June 2016, www.pinktape.co.uk (original emphasis).

${ }^{42}$ Author disclosure: as a member of the Transparency Project charity core committee, I was involved in the drafting of this proposal. See www.justice.gov.uk/courts/procedure-rules/family, in conjunction with Family Practice Direction 36J - Pilot Scheme: Transparency (Attendance at Hearings in Private).
} 
fee. Some courts, such as the Royal Courts of Justice, publish their cause lists online. 'Full' lists, which contain names, addresses and full charges, are made available to journalists by individual courts, and such access is ensured by a protocol agreement between HMCTS and two media representative groups, the News Media Association and the Society of Editors. ${ }^{43}$ These full lists may be made available to local independent bloggers as well as those working for traditional news organisations, but there is no consistent cross-court policy, which HMCTS attempted to address with new guidance issued in $2018 .{ }^{44}$ In October 2013, amendments to Criminal Procedure Rules 2013 to permit online publication of all court lists were approved by the Criminal Procedure Rule Committee, but this has not yet resulted in any major change to practice. ${ }^{45}$

With regard to the outcomes of cases, no substantial collated results data is made available to either journalists or the wider public. As will be discussed below, if such data were made available to the public, important legal and ethical questions would need to be addressed through public consultation. Some internal collation does take place which informs regular statistical publications, but the data available publicly is very limited - so much so that even the Ministry of Justice had to 'estimate' the number of defamation trials that had taken place in a given year for its impact assessment on the Defamation Bill in 2012. ${ }^{46}$ Beyond this, written judgments are either published on courts' or the main judiciary website and/or on the third party charitable site BAILII. Not all courts have consistent procedures on this, and moreover many criminal and civil cases - especially those in the lower courts do not result in a written judgment at all. Sentencing remarks in criminal cases may be made publicly available by the judiciary press office, particularly in cases attracting significant media attention, but again there is no consistent practice on this. A notable exception is the UK Supreme Court, which, as well as sending its judgments to BAILII, tracks all the stages of its cases online.

The Freedom of Information Act 2000 would have provided an ideal opportunity to put a carefully drafted positive obligation into statute, and to clarify the type of court data that should be proactively disseminated, but in fact the opposite occurred. Section 32 of the Act provides a complete exemption for court records, meaning the legislation - with its positive obligation on public authorities to provide information to the public - permits only a limited type of information to be requested about judicial and court processes and activity.

To summarise, there is a positive duty for the judiciary and courts service to make available various court materials to the public, but in practice this is not sufficiently fulfilled. The public's right to information is hampered by cumbersome and expensive systems that require physical access to court. Furthermore, complicated systems of hybrid access which usually favour journalists over other types of requesters are inadequate in a contemporary digital publishing environment. The failings of the system were exposed dramatically in the trial of Erol Incedal.

\footnotetext{
${ }^{43} \mathrm{G}$ Vassall-Adams, Reporting Restrictions in the Criminal Courts (London, Judicial College, 2015) 29.

${ }^{44}$ See HMCTS, 'Guidance to Staff on Supporting Media Access to Courts and Tribunals' (24 October 2018), https://assets.publishing.service.gov.uk/government/uploads/system/uploads/attachment_data/file/750526/ HMCTS_Media_Guidance.pdf.

${ }^{45}$ Vassall-Adans (n 43) 29.

${ }^{46}$ 'Impact Assessment', IA No MOJ 145 (Ministry of Justice, 1 April 2012) [2.230], 51, www.parliament.uk/ documents/impact-assessments/IA12-009.pdf.
} 


\section{Case Study in 'Negative Free Speech': The Incedal Case}

In 2013, a journalist spotted an unusual advance notice of a reporting restriction on the court noticeboard. If granted, it would allow an entire criminal trial to be conducted behind closed doors, with no press or public present. The media mobilised a joint response to the court, although the presiding judge, Nicol J, ${ }^{47}$ decided to hold the entire trial in camera. Such measures, deemed necessary to protect the effective administration of justice and national security, would be enforced by court order and ministerial certificates. $^{48}$

A consortium of 12 media organisations appealed. The Court of Appeal agreed with the presiding judge that there was 'a significant risk - at the very least, a serious possibility that the administration of justice would be frustrated were the trial to be conducted in open Court. ${ }^{49}$ While maintaining restrictions, it relaxed them in an unusual and hitherto unknown arrangement, with three levels of access dependent on the nature of daily proceedings. Stage 1, as it was referred to in court, was in open court, and allowed the public and the media to attend and report freely (in sessions including the swearing in of the jury, the judge's introductory remarks, verdicts and sentencing). Stages 2 and 3 were heard in camera, with the judge and court staff, the jury, the defendant, police, prosecution and defence lawyers, and - for Stage 2 only - also a small number of 'accredited' journalists present. The accredited journalists were permitted to take notes during the Stage 2 proceedings, but could not carry those notes out of court. Journalists have described how they were asked to lock their mobile phones inside a soundproof box and put their 'secret' notebooks in a safe. Additionally, they were not allowed to disclose what they had observed except to nominated legal representatives for the purpose of obtaining legal advice. According to The Guardian's Ian Cobain, journalists were instructed that this should only take place in a closed room in which mobile phones were switched off, with no notes taken. ${ }^{50}$

Importantly, the court also allowed the defendants to be named as Mounir RarmoulBouhadjar, who was charged with possessing a terrorist document (count three), and Erol Incedal, who faced the same charge (count two) and another of preparing an act of terrorism (count one). ${ }^{51}$ The unusual reporting arrangements commenced in October 2014. The second defendant, Mounir Rarmoul-Bouhadjar, pleaded guilty to possessing a terrorist document. At trial, Erol Incedal was found guilty of the same offence, but the jury failed to reach a verdict on the other charge. He was eventually acquitted at a second trial, held under the same reporting arrangements. ${ }^{52}$

\footnotetext{
${ }^{47}$ The same Nicol who co-authored Media Law (n 6), a text which makes a powerful case for the benefits of open justice. The irony was made much of by the columnist Nick Cohen, who wrote: 'Secret Justice Will Lead to Paranoia - and It's Not Very British', The Guardian, 14 June 2014.

${ }^{48}$ Such certificates are often understood as part of the law on public interest immunity (PII), but, as contended by Paul Scott, they are in fact used as a distinct mechanism for closing court from public view, 'part of a body of case law on in camera trials which has at times struggled to differentiate itself from that on PII': PF Scott, 'An Inherent Jurisdiction to Protect the Public Interest: From PII to "Secret Trials"' (2016) 27 King’s Law Journal 259.

${ }^{49}$ Incedal (n 13) [31].

${ }^{50}$ I Cobain, 'Why Is the Crux of the Incedal Case a Secret? You're Not Allowed to Know', The Guardian, 26 March 2015

${ }^{51}$ Counts two and three: an offence contrary to the Terrorism Act 2000, s 58 (collection of information); and count one: an offence contrary to the Terrorism Act 2006, s 5 (preparation of terrorist acts).

${ }^{52}$ Rarmoul-Bouhadjar and Incedal were sentenced to imprisonment for three years and three and a half years, respectively.
} 
There is no official record of how the trial divided into each stage, but the BBC reported that 10 hours of evidence were heard in public, 28 hours were heard in private with 'accredited' journalists present, and 30 hours were heard in private without any press or public attending. ${ }^{53}$ This three-tier system led to the case being widely characterised by media organisations as a 'secret trial'. Despite having privileged access, the 'accredited' journalists made clear their discomfort with the nature of the trial in articles and tweets. There was also concern about the manner in which security was controlled. The London Evening Standard claimed that one journalist 'was stopped from leaving court even though he had taken no notes', and that 'a second was threatened with arrest at his home when he had not even been in court. ${ }^{54}$

The reasons for the decisions taken during the Incedal case remain unclear, as The Times illustrated in its report on the verdict of the second trial, in a dramatic fashion: 'a law student jailed yesterday for possession of a bomb-making manual was a $\ldots+\ldots+\ldots+\ldots$. .5 The media has not been able to report the prosecution's main argument, the evidence that led the jury to find Incedal not guilty of preparing an act of terrorism, or the reason why these matters have been concealed.

Following the trial, various organisations sought to report the 'core issues' in the private sessions, but their initial applications were rejected. This decision was upheld in the Court of Appeal in February 2016, with the court finding that a departure from the principle of open justice was necessary for justice to be done. While supportive of the trial judge's decision, the justices raised concerns about procedure adopted, and also about the deficiency of information on which they had to rely. They observed that normally they would look to previous decisions to determine issues which were similar. In this case, however, relevant 'closed judgments' were 'not retained within the court files or, as far as we have been able to ascertain, in any specified place within the court. The judges requested that a working group be set up to advise the court on further action; a Practice Direction on closed judgments has since been published specifying a process for the retainment of closed judgments in certain types of proceedings. ${ }^{56}$

The case was characterised by an approach that emphasised 'negative free speech'. It saw the courts do little to facilitate public access and understanding. Indeed, events surrounding this case exposed systematic issues in the courts' managing of access. Access was only secured on the intervention by media organisations and with the court lifting its initial restrictions, rather than the court proactively considering and protecting speech from the outset.

The case also highlighted three key practical issues. First, there is no coordinated and systematic administrative procedure that guides the publicising of reporting restrictions and their application. Although notice of the restriction was advertised on a noticeboard, general knowledge of what was proposed was still reliant on a journalist being present in

\footnotetext{
${ }^{53}$ D Casciani, 'Erol Incedal: The Trial We Couldn't Report', BBC News, 26 March 2015.

${ }^{54} \mathrm{P}$ Cheston, 'Secret Terror Trial Ends in Farce as Student Is Cleared of Targeting Blair', London Evening Standard, 26 March 2015.

${ }^{55}$ S O'Neill, 'Terror Trial Evidence Must Remain Secret', The Times, 2 April 2015.

${ }^{56}$ Guardian News and Media Ltd \& Ors $v R$ \& Incedal [2016] EWCA Crim 11; Lord Chief Justice and Senior President of Tribunals, 'Practice Direction - Closed Judgments' (14 January 2019), www.judiciary.uk/ announcements/practice-direction-closed-judgments/.
} 
court and alert to the irregularity of the situation. It appears that there was no proactive notification of any media organisation through other channels in this case.

Second, decisions can be arbitrary. The resource and experience of legally represented media organisations allowed them to bring a challenge and to secure 'accredited' status for their journalists. The court failed to consider the rights of smaller forms of media, such as specialist and online-only platforms. Furthermore, it may have been valuable to have non-media observers present during the Stage 2 proceedings, who would play a different watchdog role in holding the judicial process to account and whose reporting would not have been constrained by a media organisation's agenda (which is necessarily guided by the newsworthiness of particular details). Lawrence McNamara has suggested that there is a strong case for giving legal professional bodies and specialist NGOs a similar status as independent observers..$^{57}$

Thirdly, there is a paucity of material on transparency decisions themselves, with previous cases not properly documented in the court system. (This also occurred with the granting of so-called super injunctions and anonymised privacy injunctions before a new procedure was introduced in 2011 following a report by the Master of the Rolls. ${ }^{58}$ It has since transpired, however, that the data is not necessarily complete, and the collection system is being reviewed by the judiciary. ${ }^{59}$ )

The way in which the publicity of this trial was handled has been widely criticised, and not only by the media. The Lord Chief Justice, Lord Thomas, said that 'there ought to be very much clearer guidelines and rules' in future. He stated that the press should be able to 'see such material as can be shown to them so they know what the argument is about' and hoped that a 'proper way of dealing with [anonymised defendants]' could be developed. ${ }^{60}$

\section{Case Study in 'Positive Free Speech': The Leveson Inquiry}

In contrast to court and tribunal proceedings, public inquiries have sometimes taken a much more proactive approach in protecting judicial and executive accountability and supplying information to a public audience. More could be done to improve the formats of digital evidence and reports to make them more searchable and accessible to public audiences, but in general they show how judicial proceedings can be shared with a wide audience, albeit that public inquiries are distinct from other types of court proceedings and instigated to investigate particular events that have caused or are capable of causing public

\footnotetext{
${ }^{57}$ L McNamara, 'Secret Trials - a Little Transparency, a Lot to Worry About', UK Human Rights Blog, 12 June 2014, https://ukhumanrightsblog.com/2014/06/12/secret-trials-a-little-transparency-a-lot-to-worry-about-lawrencemonamara.

${ }^{58}$ Committee on Super-Injunctions, Super-Injunctions, Anonymised Injunctions and Open Justice (London, Master of the Rolls, 2011).

${ }^{59} \mathrm{~J}$ Townend, "Where Did All the Privacy Injunctions Go? A Response to the Queen's Bench "Media List" Consultation', Inforrm's Blog, 31 May 2017, https://inforrm.org/2017/05/31/where-did-all-the-privacy-injunctionsgo-a-response-to-the-queens-bench-media-list-consultation-judith-townend.

60 'Transcript of Lord Chief Justice's Annual Press Conference 2014' (12 November 2014) 4, www.judiciary.gov. uk/wp-content/uploads/2014/11/lcj-transcript121114.pdf.
} 
concern. The Leveson Inquiry, established by the Prime Minister, David Cameron, in July 2011 , broke new ground in the way it was communicated online, and was the first inquiry under the Inquiries Act 2005 that properly utilised online space. It was also the first to be accompanied by a continual stream of third party social media commentary. ${ }^{61}$

The Leveson Inquiry was bound by the terms of section 18 of the Inquiries Act 2005 , which states that an inquiry must allow public access to inquiry proceedings and information:

(1) subject to any restrictions imposed by a notice or order under section 19, the chairman must take such steps as he considers reasonable to secure that members of the public (including reporters) are able:

(a) to attend the inquiry or to see and hear a simultaneous transmission of proceedings at the inquiry;

(b) to obtain or to view a record of evidence and documents given, produced or provided to the inquiry or inquiry panel.

A narrow reading of section 18(1) could mean merely facilitating physical access at the court rather than via a website. Lord Justice Leveson's approach indicated a more expansive interpretation, with timely and extensive communication of the inquiry online. A bespoke website made a range of material available during the inquiry's proceedings: information about the inquiry, rulings by Lord Justice Leveson (on core participants or admissibility of evidence, for example), transcripts of evidence and written evidence (once formally read in). Most importantly, proceedings could be watched live or at a later date online, except for a few rare examples in which anonymity or special provisions applied. This opened the hearings to people unable to travel to court.

The courtroom itself had limited public and media access, and so an overflow Annexe (a marquee in the Royal Courts of Justice grounds) was opened, with sections for the media and the public to watch the proceedings from several screens. This had both pros and cons: while it allowed journalists to work in perhaps a more comfortable and relaxed environment, and view a scrolling transcript, they lost court-side immediacy. Journalists were also limited by the fact that they did not have access to the documents as they were discussed in the inquiry. The document appeared on the screen in the Annexe, but as one reporter covering the inquiry explained, 'you were trying to take down the document at the same time as you were trying to listen to people being questioned. ${ }^{62}$

The inquiry was also communicated via Twitter, although not in an official capacity; the inquiry's own Twitter account only published one update between July 2012 and the report's publication in November. It was used for posting notifications about updates to the website, rather than interacting with online followers. The surrounding conversation was diverse and interactive. Largely uninhibited by the strict contempt restrictions that would generally apply in court proceedings, a range of commentators - including campaigners, journalists, bloggers and academics - reported and commented on what was taking place. Sometimes this activity played a key part in extending the 'public watchdog' role of the

\footnotetext{
${ }^{61}$ While the Sir John Chilcot's inquiry into the Iraq War, which heard evidence from 2009 to 2011, was also broadcast live and tweeted about, it was not a public inquiry under the Inquiries Act 2005.

${ }^{62} \mathrm{~W}$ Turvill, 'Reporting the Reporters: Interviews with the Journalists Who Covered Leveson', Press Gazette, 6 November 2012.
} 
press, drawing attention to key passages and sharing important information in the public interest. At other times, it was flippant and trivial. For example, one of the inquiry counsel gained notoriety - partly due to further promotion by the mainstream media - during an episode in which Twitter users mocked her for apparently gazing at witness Hugh Grant during his evidence, tagging their updates '\#womanontheleft'. ${ }^{63}$

The Leveson Inquiry recognised the distinct role of reporters and journalists, but also the part of the broader public audience. This reflected section 18(1) of the Inquiries Act 2005 , the wording of which indicates that reporters are a special sub-set of the public. In the inquiry, reporters were given special privileges: a small number had guaranteed access to press seats in courtroom 73, a portion of the Annexe was reserved for the press, and they received communications from a dedicated press officer. It is likely that the timing of the report's release on 29 November 2012 to a room of invited journalists was chosen to suit a broadcast media schedule. Perhaps to avoid partisan national newspapers dominating the coverage with their take on the findings, Leveson LJ announced the report in a statement at lunchtime, which gave the broadcasters, regulated by rules of impartiality, a chance to run their reports in the afternoon and evening television and radio news bulletins, alongside the newspapers' online coverage but ahead of the next morning's front pages.

In these ways, priority was given to national news media actors, but this was not at the cost of public access. After the report was released, hyperlinks to the report's four volumes and the executive summary were published on the website. Since the conclusion of part one of the inquiry (the government has decided that part two will not proceed), the website materials and video have been preserved by the National Archives. Furthermore, on more than one occasion, wider public - rather than institutional media - interests were given the greater weight. When media organisations challenged the admission of evidence from anonymous journalists represented by the National Union of Journalists, Lord Justice Leveson found in favour of the latter's Article 10 rights. ${ }^{64}$

The online communication - both during and following the Leveson Inquiry - is to be commended, although there are ways in which it could have been made even more accessible. The transcripts and report were published in cumbersome non-machine-readable formats, which limited their accessibility. Third parties have attempted to make the vast and rich outputs more useable, although this has required a significant investment of time. A service offered by the civic organisation 'mySociety' has produced search-friendly HTML versions of the transcripts, which cross-reference related material. ${ }^{65}$ This allows, for example, a user easily to search all the oral evidence for a particular phrase (eg 'data protection') or by witness, which would not be possible with the original formats. Robert Sharp, a writer and free speech campaigner, also converted the report into HTML to allow better functionality; his version cross-references parts of the multi-volume report with hyperlinks, allowing for improved reader comprehension and navigation. ${ }^{66} \mathrm{~A}$ third offering is Discover Leveson, a searchable public archive, published by the journalism department at Kingston University. ${ }^{67}$

\footnotetext{
${ }^{63}$ See Townend (n 5) 19.

${ }^{64} R$ (on the application of Associated Newspapers Ltd) $v$ Rt Hon Lord Justice Leveson [2012] EWHC 57 (Admin).

${ }^{65}$ Available at leveson.sayit.mysociety.org.

${ }^{66}$ Available at http://leveson.robertsharp.co.uk.

${ }^{67}$ Available at https://discoverleveson.com/.
} 
Unlike the Incedal trials, which took place two years later, the Leveson Inquiry was predominantly characterised by an approach of 'positive free speech', where access was not only secured by the intervention of third parties challenging restrictions; the inquiry proactively considered, promoted and protected speech from the outset. Although the evidence and report could have been made even more accessible to online readers, the chair considered public access beyond the terms of the Inquiries Act, and gave the public audience an opportunity to access materials directly without relying on a mainstream media proxy. In this way, public accountability and the public right to receive information was not only served through passive policies of access, or reactive decisions.

It is important to note, however, that Lord Justice Leveson went beyond what he was required to do by statute. The openness of an inquiry is still very much at the discretion of the chair, and a less diligent chair may not have made such great efforts to publicise materials effectively. Clearer guidance for inquiries would give better protection to this type of 'positive free speech'. It would help inquiry chairs navigate questions over digital publications: for example, the nature of material that should be published and when it should be published became important questions during the Azelle Rodney Inquiry in 2012. ${ }^{68}$ It could also recommend publication methods to inquiry chairs that would enable more userfriendly formats than enormous PDFs, and make explicit the arrangements for archiving proceedings in the National Archives.

Finally, it should be remembered that a public inquiry is distinct from ordinary court proceedings, and this has aided the greater openness of inquiry proceedings. A public inquiry will have greater financial resources to allow the appointment of a dedicated press office and special audiovisual and online technology arrangements. Additionally, while an inquiry may be alert to any potential contempt arising from the evidence (affecting an ongoing related trial, for example) it is free from many of the contempt of court issues that must be dealt with in the courts when publicising their activities.

\section{Open Data from the Courts}

The obligation to open proceedings can be understood as a positive measure, but as the case studies above illustrate, this can take many different forms, depending on the type and particular circumstances of the proceeding, the attitude and interpretation of the presiding judge, and interventions by the parties involved. The criteria for openness are somewhat hazy. How might more clarity be achieved? One solution might be to look to the government's policy on open government and its standards on open data.

Four UK Open Government National Action Plans have promised to improve public access to data. The government committed to identify and publish, in the period 2016-18, core data assets to create 'a high quality national information infrastructure, making government data more secure and easier to find, store and access', and to make better use of data assets. It promised to 'encourage and support data-driven techniques in policy and service delivery across government departments and encourage the better

\footnotetext{
${ }^{68}$ Transcript of the oral hearing of 4 September 2012, webarchive.nationalarchives.gov.uk/20150406091509/ http://azellerodneyinquiry.independent.gov.uk/transcripts/269.htm.
} 
use of open data in the economy and civil society' ${ }^{69}$ Its latest plan 'recognises the need to deepen previous commitments and improve the quality of the data that has been released. ${ }^{70}$ Separately, the Ministry of Justice's Single Departmental Plan for 2015-2020, now withdrawn, promised to: 'open up as much data as possible overall across the MOJ and the National Offender Management Service to enable researchers, academics, charities, the media and the wider public understand what is happening in the criminal justice system. ${ }^{71}$ Notably, this specific commitment is not present in the latest Single Departmental Plan; its ambition for data and transparency is drafted in vaguer terms. ${ }^{72}$

On the surface, these strategic ambitions seem ideal vehicles through which to enforce a positive free speech agenda. A commitment to open data means publishing data that can be accessed, shared and reused; such publication should be made in an open format, [that] is machine readable and is published under a license that allows for free reuse. ${ }^{73}$ Specific court data could be opened up in these formats under such an obligation, releasing it from the control of private third parties and allowing the public to access data directly without relying on imperfect media proxies.

For some data, this might be the right approach. If it is appropriate for the data to be accessible through search engines and to be reused by any third party - corporate or nonprofit - then the courts and Ministry of Justice should certainly consider collecting and publishing data as open data. However, it may be inappropriate for some forms of nonanonymised data. For example, if HMCTS started to collate complete and accurate sets of listings and results data in the criminal courts, which may include individuals' names and addresses, should this be published as open data? Offender rehabilitation rights and the so-called 'right to be forgotten', or erasure, recognised in data protection law, would need to be seriously considered before doing so.

There is a valid discussion to be had on what types of data should be open data, and whether some data sets should be licensed under particular conditions. In other words, the data could be made accessible without being published as open data. There may be alternative licensing regimes for data sets, or ways of centrally controlling data access that would allow appropriate access control in the context of some court data. Whatever formats are determined as appropriate for different data sets, there is a timely opportunity for government and the judiciary to improve and overhaul the gathering and collection of court data with a view to different forms of publication, as the government moves forward with its national plan. ${ }^{74}$

\footnotetext{
${ }^{69}$ UK, Cabinet Office, 'UK Open Government National Action Plan 2016-18', policy paper (12 May 2016), www. gov.uk/government/publications/uk-open-government-national-action-plan-2016-18/uk-open-governmentnational-action-plan-2016-18.

${ }^{70}$ Department for Digital, Culture, Media and Sport, 'UK National Action Plan for Open Government 2019-2021' (12 June 2019), www.gov.uk/government/publications/uk-national-action-plan-for-open-government-2019-2021/ uk-national-action-plan-for-open-government-2019-2021.

${ }^{71}$ Ministry of Justice, 'Single Departmental Plan: 2015 to 2020' (19 February 2016), www.gov.uk/government/ publications/moj-single-departmental-plan-2015-to-2020/single-departmental-plan-2015-to-2020. The specific mention of 'criminal justice' is significant. Civil matters have been given much less attention than crime in the government's agenda on open data.

${ }^{72}$ Ministry of Justice, 'Ministry of Justice Single Departmental Plan 2019-2022' (27 June 2019), www.gov.uk/ government/publications/ministry-of-justice-single-departmental-plan/ministry-of-justice-single-departmentalplan-3.

${ }^{73}$ A Acuña, 'A Simple Intro to Open Data' (4 November 2013), https://data.blog.gov.uk/2013/11/04/a-simpleintro-to-open-data/.

${ }^{74}$ Author disclosure: as a consultant to the NGO Spotlight on Corruption, a member of the Open Government Network, I have advised on options for a draft commitment to open justice in the next action plan (2021-2023).
} 


\section{Conclusion: Rethinking Access to Court Information}

Using the conceptual framework for positive free speech developed in this collection and at a workshop that preceded its publication, this chapter has shown the ways in which positive and negative free speech is present in the UK court system at both the theoretical and the practical level. Accepting the proposition that positive free speech is beneficial to a functioning democracy, it posits that the state should extend its positive free speech obligations in this domain, and more adequately fulfil those that already exist. In view of the changing media landscape (including a decline in specialist legal coverage), and the digital tools available, the courts should make more proactive positive interventions to protect speech and, in tandem, open justice.

It is at the practical level that free speech is most at risk; the existing provisions in common law and statute - which can be understood as providing a positive obligation on courts - allow for practice that can significantly inhibit an individual's right to access information in the following ways.

First, the system is overly reliant on the proactivity and interventions of print and broadcasting media organisations. It cannot be assumed that media concerns represent public concerns, and the media may choose not to report or intervene in cases where the output is not obviously 'newsworthy', or may focus on acquiring information that serves media interests (eg being able to name child defendants) and neglect other sorts of information which may fulfil other civic interests (eg legal argumentation). Additionally, there is a wellremarked decline in systematic and specialist court reporting by the traditional media owing to a reprioritising of resources. If this pattern continues, the public will need other means through which to access information from court. This could be provided by academic and not-for-profit initiatives, which do not currently enjoy the status and access of the press in court processes. Improving and lowering the costs of access to court documents would offer access for those otherwise inhibited by their financial circumstances or by a disability.

Secondly, the publicity system is often inconsistent and arbitrary, with inadequate documentation of its decisions on transparency, as was exposed by the trials of Erol Incedal. Precise guidelines are needed, informed by consultancy among the different parties, or their representatives, involved in court processes (eg lawyers, victims, witnesses, the media, academic researchers, third sector campaigners) and the wider public, on the way in which different sorts of court data should be handled and proactively communicated to public audiences. Any system should not be 'one-size-fits-all', but rather should be appropriately designed for different types of civil and criminal proceedings. Such an approach could include implementing a well-designed digital system for sharing information about intended or active reporting restrictions, further developing the Law Commission's proposed model.

A more clearly defined procedure for deciding on the appropriate publicity for a case, including digital publication of materials, would also help protect the effective administration of justice, and legitimate ECHR rights associated with, for example, child welfare, family and private life, and national security. It could also offer greater accountability of court decisions relating to transparency of proceedings. A passive and reactive system of non-censorship does not provide adequate free speech or open justice protection; more positive free speech, delivered through obligations on the judiciary and courts proactively to communicate what happens in court, would serve a broadly defined public interest and enable fuller participation in civic life. 
